\author{
6. 電力・ガス(発電，供給技術） \\ 6.12001 年の電気事業の展望 \\ 〜技術開発を中心として〜 \\ (キーワード 電力供給·需要の展望, 電力利用技術, 電力供給技術 $)$
}

-1988. 9.7 受理一

東京電力株式会社 上田 雅美 ${ }^{* 1}$, 藤原万喜夫*2

\section{1.はじめに}

この 1,2 年の間, 各産業から 21 世紀に関する展望 が次々と出された。一時は, 21 世紀ビジョン・ブーム といった様相ですらあった。こうした現象が起こった のは, 21 世紀を, 今後 10 数年とい5身近な時代の内に とらえることができるといら, 単純な理由からではな いであろう。そこには, わが国経済社会が, 現在大き な転換点に立っているといった認識があるためと考兄 られる。たとえば，民営化による日本電信電話(橵)誕 生, 通信事業の自由化は, 高度情報社会到来を予感さ せるし, 最近の内需主導による景気の回復は, 輸出に 依存し，欧米先進諸国へ追いつくことを目標としてき た，わが国の経済構造が大きく変わろらとしているこ とを感じさせるものである。さらには, 行政改革, 教 育改革, 税制改革といった一連の改革論議は, 21世紀 へ向けてわが国そのものが生まれ变わっていかなけれ ば対応できない，といった認識のあらわれでもあろら。

われわれ電気事業の周囲に限定しても, 近年の情勢 変化を物語るものが数多くある。たとえば, 電力需要 の伸びは, 電灯, 業務用といった生活関連需要主導型 となりつつある。これと同時に, 業務用分野における コンピュータ利用の拡大やオンライン網の整備などに 伴って, 電圧, 周波数, 供給信頼度といった「電力の 質」に関するニーズは高まる一方である。また，エネ ルギーに寄せられるニーズの多様化といった需要面の 变化と, エネルギー供給技術の進歩が結び付いた結果, コージェネレーション(熱電併給)といったものが登場

\footnotetext{
$* 1$ 技術開発本部 $* 2$ 企画部

東京都千代田区内幸町 $1-1-3$
}

しつつある。コージェネレーションを例にとってみれ ば明かなとおり, これまで照明や冷房は電気, 給湯, 暖房, 調理は石油·ガスといった具合に, 各ェネル ギーそれぞれの棲及分けがなされてきたものが，各エ ネルギーを隔てていた垣根が取り払われることによっ て, エネルギー間競合が創出されつつある。すなわち, 電気事業を含めたエネルギー業界に, 競争と選択の時 代が訪れつつあるといえよう。このような動きは, 先 に述べた通信事業の自由化に代表される規制緩和の流 れとも相まって, 今後も, より一層強まっていこう。 動きの行末如何では, 電気事業にとって, これからの 事業体制，事業活動のあり方を再検討せざるを得ない 状況が起こる可能性もあろう。

電力需給に限ったことではない。電気事業の活動す る領域も，つい数年前では考えられなかったほど幅広 いものとなりつつある。電気事業や地域熱供給事業な ぞ，電気事業がこれまでに蓄積してきた資産と技術を 有効に利用でさる周辺分野への進出に対する, 期待が 盛り上がりつつある。さらには都市再開発事業遂行の ための, ューディネータ役など, 地域の経済社会振興 へ向けての期待もまた大きなものとなりつつある。こ れらの活動が活発となった場合には, 電力の低廉かつ 安定的な供給という事業本来の活動に,よりよい影響 を及ぽすことはもちろんのこと電気事業の事業内容そ のものが大きく変貌していく可能性すら感ずることが できる。

このような時代的な転換期にあたって，来たるべき 時代に柔軟に対応していくためには, 時代の方向性を 読み取るとともに，予想される変化に対して先見的に 
対応していくことが必要となろら。以上の認識にたっ て, 昭和 61 年秋にまとめられたものが，「電気事業の 21世紀ビション」である。その後, 21 世紀へ向けての エネルギー需給や電力需給をめぐって，62年10月には, 総合エネルギー調査会, 電気事業審議会の両需給部会 より，それぞれ「長期エネルギー需給見通し」，「長期電 力需給見通し」が出された。「電気事業の 21 世紀ビジョ ン」が出されてから 2 年が，また「長期エネルギー需給 見通し」および「長期電力需給見通し」が出されて以来， ちょらど 1 年が経過しょうとしているが，21世紀に対 する考光方は，基本的には変わっていないと考元られ る。本稿は，以上の 21 世紀展望をもとに，21世紀にお ける電力需給の見通しや，技術開発の方向性などにつ いて述べたものである。

\section{21 世紀における電力需要}

\section{1 経済社会の動向と電力需要}

21世紀に向かってのわが国経済社会においては，価 值観の多様化やアメニティ意識の高まりが, 従来にも 增して，進行していくことが予想される。他方，人口 の高齢化や女性の社会進出といった動きは，技術革新 の潮流と複合化して，生活手段の高度化等を生み出す こととなろう。すなわち快適な生活, 新しい生活手段 へのニーズが高まってくるものと思われる。エネル ギーに寄せられる新しいニーズの発生は，何も生活面 に限られたことではない。産業面においても，加工組
立型産業のウェイト増や，情報，医療，健康，教育と いった新たなサービス産業の進展に伴って, エネル ギーに対するニーズは多様化し，かつ高度化していく ものと予想される。

このような経済社会の変化のもとで, 電力の選好性 は，これまでにも増して高まることが予想される。と いらのは，電力には，以下に述べるような他のェネル ギーには特長を有しているからである。

(1) 照明, 動力, 熱, 通信，エレクトロニクスなど, 様々な分野への利用が可能であること。

(2) 安全かつ簡単に利用することができること。

(3)きわめてクリーンであること。

(4) 精密な制御が可能であること。

以上のことを考慮すると，電力は，エネルギーの中 でも高い伸びを示すことが容易に想像できよう。

\section{2 今後の電力需要の見通}

表 1 に，昭和70年度， 75 年度における電力需要の見 通しを示した。これは昨年10月に出された，電気事業 審議会の需給部会中間報告によるものである。これに よれば, 今後の総需要電力量は, 75 年度 (西暦2000年) において，8，380億 $\mathrm{kWh}$ 程度と見込まれている。すな わち，今後のおよそ15年間を $2.4 \%$ の伸びで推移する ものと想定されている。

ところで，今後の電力需要の内訳については次節で 述べることとするが，総エネルギー需要との関係と対

表 1 電カ需要の見通し

(単位：億 $\mathrm{kWh}$ )

\begin{tabular}{|c|c|c|c|c|c|c|}
\hline \multicolumn{2}{|c|}{ 区 分 } & 61 年度実績 & 70 年 度 & 75 年 度 & $\begin{array}{c}\text { 伸び率 } \\
70 / 61 \\
(\%)\end{array}$ & $\begin{array}{c}\text { 伸 び 率 } \\
75 / 70 \\
(\%)\end{array}$ \\
\hline 民 & 生 & $\begin{array}{l}2,492 \\
(41.4)\end{array}$ & $\begin{array}{l}3,490 \\
(47.3)\end{array}$ & $\begin{array}{l}4,210 \\
(50.2)\end{array}$ & 3.8 & 3.8 \\
\hline 産 & 業 & $\begin{array}{c}3,526 \\
(58.6)\end{array}$ & $\begin{array}{r}3,890 \\
(52.7)\end{array}$ & $\begin{array}{l}4,170 \\
(49.8)\end{array}$ & 1.1 & 1.4 \\
\hline 総 & 需 & $\begin{array}{l}6,018 \\
(100)\end{array}$ & $\begin{array}{l}7,380 \\
(100)\end{array}$ & $\begin{array}{l}8,380 \\
(100)\end{array}$ & 2.3 & 2.6 \\
\hline 再 & 電 気 事 業 月 & $\begin{array}{l}5,377 \\
(89.4)\end{array}$ & $\begin{array}{c}6,700 \\
(90.8)\end{array}$ & $\begin{array}{l}7,650 \\
(91.3)\end{array}$ & 2.5 & 2.7 \\
\hline 掲 & 自家発自家消震 & $\begin{array}{r}641 \\
(10.6) \\
\end{array}$ & $\begin{array}{r}680 \\
(9.2)\end{array}$ & $\begin{array}{r}730 \\
(8.7)\end{array}$ & 0.7 & 1. 4 \\
\hline \multicolumn{2}{|c|}{$\begin{array}{l}\text { 最大需要電力 (万 } \mathrm{kW} \text { ) } \\
\text { (電気事業用) }\end{array}$} & 11,054 & 14,300 & 16,300 & 2.9 & 2.6 \\
\hline \multicolumn{2}{|c|}{ 年 負 荷 率 （\%) } & 59.0 & 56.8 & 56.8 & - & - \\
\hline
\end{tabular}

（）内は構成比 $(\%)$ （出所）電気事業審議会 需給部会 中間報告 (62年 10 月) 


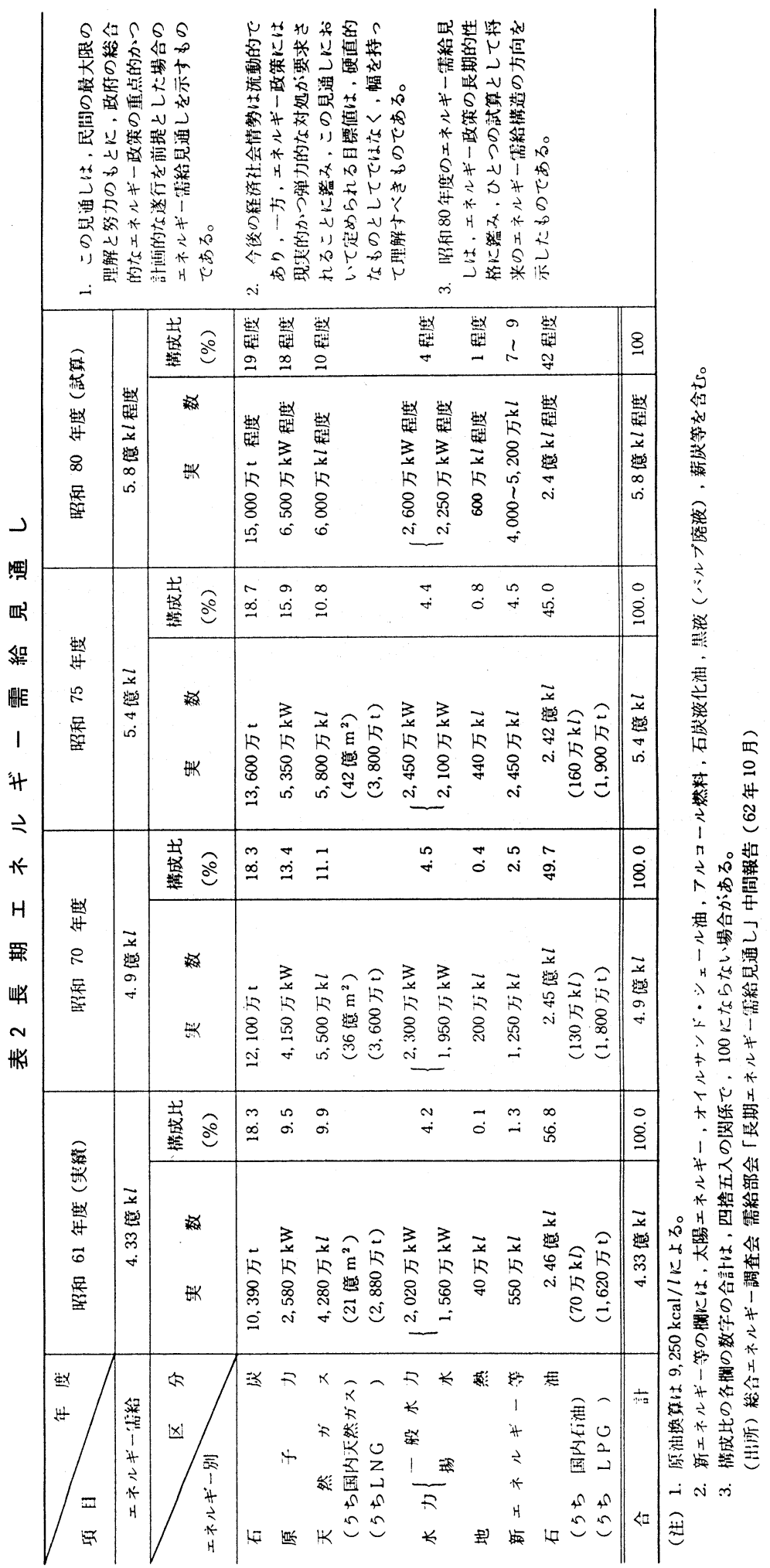

比してみると，先に述べたとお り, 電力需要には, 総ェネル ギー需要に比べて，高い伸びが 見込まれていることがわかる。 ちなみに時を同じくして，昨年 10 月に出された, 総合ェネル ギー調査会需給部会の中間報告 (表 2 )によれば，わが国の総エ ネルギー需要の伸びについては, 61 年度 75 年度の 14 ケ年の年平 均增加率が1.6\%となっている。 すなわち, 電力需要の伸びは, 総エネルギー需要の 1.5 倍もの 伸びを示すものと考えられてい るのである。この結果, エネル ギー需要の電カシフトが進み, 電力化率は 61 年度の約 $37 \%$ から, 75 年度には約 $42 \%$ へ高をるこ とが見込まれているのである。

一方，最大電力については， 75 年度には 1 億 6,300 万 $\mathrm{kW}$ と， 今後およそ15年の間に 1.5 倍の 需要規模に達するものと予想さ れる。最大電力は, これまでも 生活関連需要に掂ける冷房機器 の普及拡大を背景に, 電力量を 上回る伸びを示してきた。今後 についても，引き続き冷房機器 の普及が見込まれるほか，サー ビス産業，加工組立型産業など の昼間操業型の需給のウェイト 増に伴って, 電力量を上回る伸 びを続けるものと予想される。 ちなみに，61〜 75年度の 14 ケ年 の年平均増加率は, $2.8 \%$ 程度 と想定されている。

\section{3 部門別電力需要の動向}

2.3.1堅調な伸びの見込ま れる生活関連需要

まず家庭用需要については， 従来, 電気機器の普及などを背 景に堅調な伸びを示してきた。 今後についても, 人口の増加, 世帯数の増加, さらには新型機 器の普及などによって堅調な伸 
びを続けるものと予想される。とりわけ，高㱓化や女性 の社会進出に伴ら生活様式の変化が，ホームオート メーションなどの新たな需要を生み出すところとなろ 5。

また業務用電力については，これまでも，第 3 次産 業の伸び, 都市機能の高度化, オフィスオートメーシ ョンの普及などによって，経済成長を上回る伸びを示 してきた。今後についても, 都市化の進展を背景に, 都市空間の高度利用を目指して, ビルの大型化·高層 化はますます進んでいくものと考光られる。加えて， ソフト化，サービス化経済への移行を反映して，業務 用電力は各需要の内で最も高い伸びを示していくこと となろら。

以上のとおり, 生活関連需要は, 今後子堅調に推移 するものと見込まれる。この結果, 総需要に占める生 活関連需要のウェイトは今後も引き続き上昇して, 75 年度にはついに， 5 割を超えるものとなろう。すなわ ち21世紀には, 伸びの点でも, 総需要の点でも, 生活 関連需要が主体を占めることとなるのである。

2.3 .2 低い伸びにとどある産業用需要

鉄鋼，化学，アルミ精錬など，エネルギー多消費型 産業の停滞, 電子·電気機械などを中心とする加工組 立型産業の伸びに代表される産業構造の变化を反映し て，産業用電力需要は低い伸びにとどまってきた。確 かにここ1,2年については，物価安定，金利低下，さ らには 6 兆円に及ぶ緊急経済対策の効果などを背景と して, 景気が回復·拡大し, 産業用需要も一転して, 高い伸びを示しつつある。しかし，長期的な視点にた った場合，エネルギー多消費の素材型産業は，停滞の 方向に向からと考光る方が自然であろう。加えて，製 法転換や技術革新などによる省電力化や，プロセス管 理の徹底などによる電力使用合理化が推し進められる ことが予想される。こうしたことを考虑すると，長期 的には産業用需要は, 生活関連需要に比べて, 低い伸 びにとどまらざるを得ないであろう。

\section{4 需要面での課題と対応方向}

今後の需要については，以上のと拈りであるが，需 要面からみた電気事業にとっての課題と, その対応方 向について触れてみたい。

第 1 亿土ネルギーにおける競争と選択の進行である。 21 世紀へ向けて, エネルギー低成長時代が次第に進行 していくものと予想される。これに伴って, ェネル ギー間の競争と選択は, 従来以上に激化していくもの 之考光られる。一方, お客さまの立場にたった場合に は, 競争の激化によって, より低廉でより高度なサ一 ビスを享受できる可能性もある。電気事業としても，
都市再開発への積極的参加，新しい電気利用システム ·機器開発への関与などを通じて, 顧客サービスの充 実, さらには地域社会発展への貢献に努めていくこと が，自らの発展につながっていくこととなろら。

第 2 には, 電力品質に対するニーズの高まりである。 情報化の進展, 電力化率の上昇に伴って, 電気の品質 に対する要求は，これまで以上に厳しいものとなろう。 現在に打いても, 停電や電圧.周波数変動が社会に与 える影響は大きなものとなっているが，将来において は，現代とは比べょらもない汪ど，大きなものとなっ ていこう。電気事業としては, 電力流通設備の信頼度 向上に努めるとともに, 配電線運用の自動化, 無停電 工法の開発などに積極的に取り組まねばならないであ ろら。また, 高品質の電力供給に対しては, 場合によ ってはお客さまと電気事業者が協力して対策に取り組 む必要も出てこよう。

第 3 には，お客さまの二ーズの多様化である。価値 観の多様化や個性化といった流れは, 電力需給の分野 においても，多様な選択の可能性を求める動きにつな がっていこう。したがって, 電気事業としては, 料金 制度の面において幅広いメ二ュ一の検討を進めること はもちろんのこと, 新しい生活スタイルの中での新し い商品メニューの提供といったレベルにまで, 営業活 動の質を高めていかなければならないであろう。

第 4 亿は，産業空洞化の可能性である。製造基地の 海外移転, あるいは製品輸入などに代表される産業の 空洞化は, 貿易摩擦, 通貨情勢如何では, 急速に進む 可能性がないわけではない。たとえば，製造業の海外 進出が大規模に進んだ場合には, 産業用電力需要は大 幅に減少するところとなる。それは，これまでの電力 需要の主要な部分を占めてきたもので，いわば電力需 要の核ともいうべきものを衰失することを意味してい る。したがって, 電気は製品に体化して輸出入されて いく商品であるといら意識を持ちつつ，産業の空洞化 に注意を厸っていかなければならない。

最後に，技術開発動向である。現在から21世紀にか けて，エレクトロニクス，新素材，バイオなどを中心 に技術革新が開花期を迎えていくこととなろら。超電 導, 燃料電池, 太陽光発電, コージェネレーションな ぞの技術革新は，将来のエネルギー市場の様相を大き く变化させていく可能性をはらんでいる。加えて, 電 力供給サイドにとっても，これらの技術進歩の成果を 採り入れることで，口ードマネジメントの可能性を追 求できることにもなる。電気事業は, 技術開発の成り 行きに大きな関心を払うとともに，自らも研究開発に 
積極的に取り組んでいく必要があろう。

\section{21 世紀をめざしての電力供給構造}

\section{1 電力供給設備をめぐる変化の方向}

現在でこそ，国際石油情勢は落ち着きを見せてはい るものの，エネルギー消費の少ない開発途上国の経済 が発展したりするのに伴って, 長期的にはエネルギー 需給はひっ迫するであろら。このため, 将来的には, 資源の不足からエネルギー価格の上昇はさけられない ものと予想される。したがって, 先進国の中でも, エ ネルギー基盤の脆弱なわが国にとっては, 脱石油化, エネルギー源の多様化を進めることは, 国家的課題と もいえよう。電気事業としても, 原子力を中心とする 石油代替電源開発を着実に促進していかなければなら ないのはいらまでもないことである。そのステップを 着実に進めることが, 結果的には石油依存度を低下さ せることとなるのである。各種の電源および新エネル ギーの方向性に関して述べれば，以下のとおりである。

まず原子力については，現在の軽水炉技術の一層の 高度化をはかるとともに, 大規模集中開発のメリット を活用することなどによって，コストダウンを推進し ていく必要がある。その結果, ベースロード用電源と
しての経済的優位性が一段と向上することとなろう。 一方，ウラン濃縮・使用済燃料再処理工場などの原子 燃料サイクル施設の完成は, 原子力を準国産エネル ギーとして位置づけることができることを意味してい る。この点からは, エネルギー供給におけるセキュリ ティ確保面からの原子力の必要性は一段之高まるもの と予想される。これらを考慮すると，原子力は，従来 にも増して最優先で開発されるべき電源であると評価 できよう。

石炭火力については, 石炭の埋蔵量がきわめて豊富 であり，その賦存地域も，米国，中国，オーストラリ アなどを中心に，ほぼ世界中に広がっており，供給の 安定性の高さから, 将来の主要電源の一翼を担らもの として評価することができよう。このため，合理的な 環境対策やガス化をはじめとする石炭利用技術の高度 化，さらには大量の海外炭の輸送，処理問題など技術 的な諸課題を克服することが期待されるところのであ る。

一方，LNGについては，生産から消費まで一貫し たシステムとして開発されるほか，供給が長期にわた って継続されるといった特徵を有している。加えて,

表 3 年度末 電 源 構 成

(単位：万 $\mathrm{kW}$ )

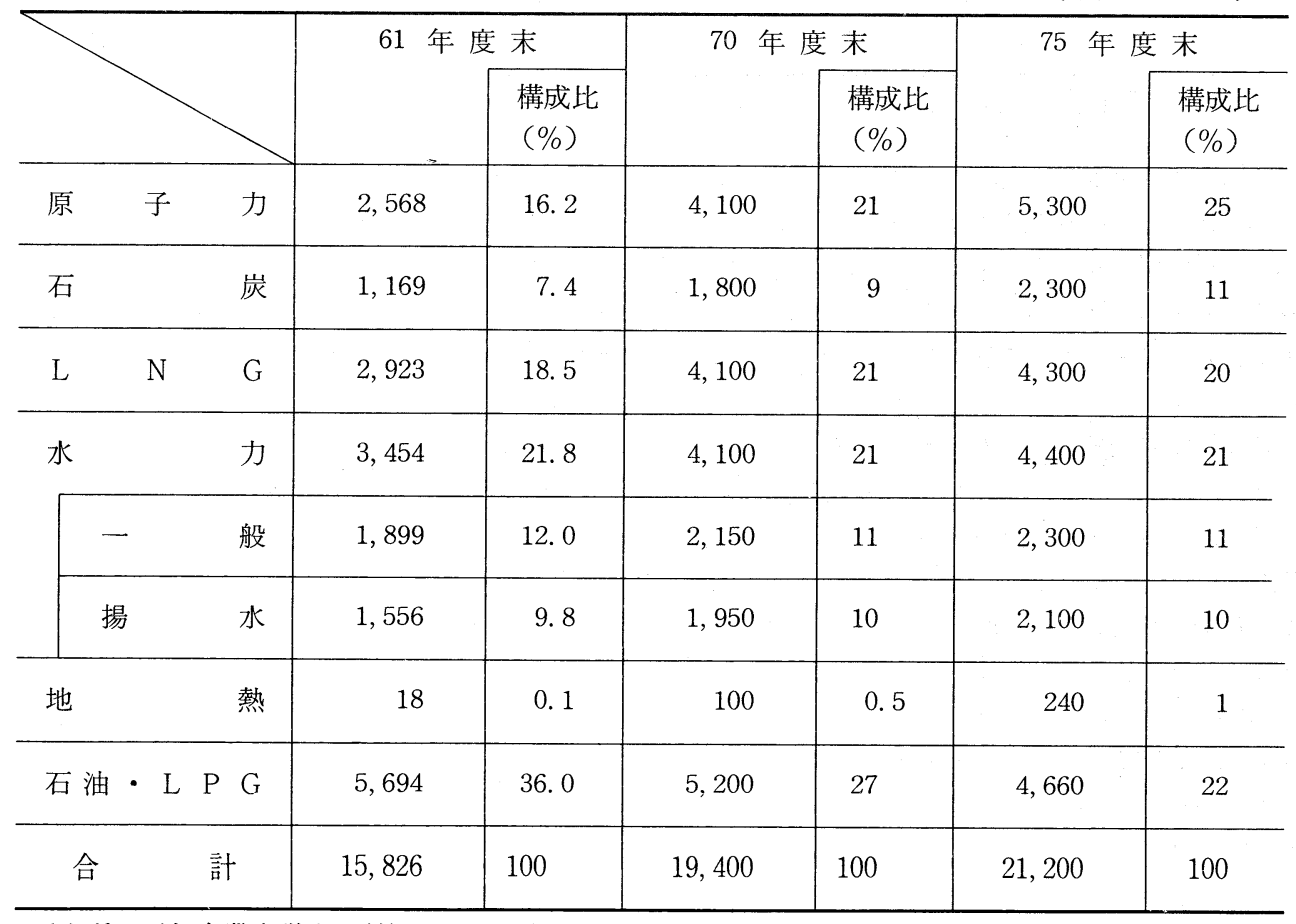

(出所) 電気事業審議会 需給部会 中間報告（62年10月） 
表 4 電 力 供 給 目 標

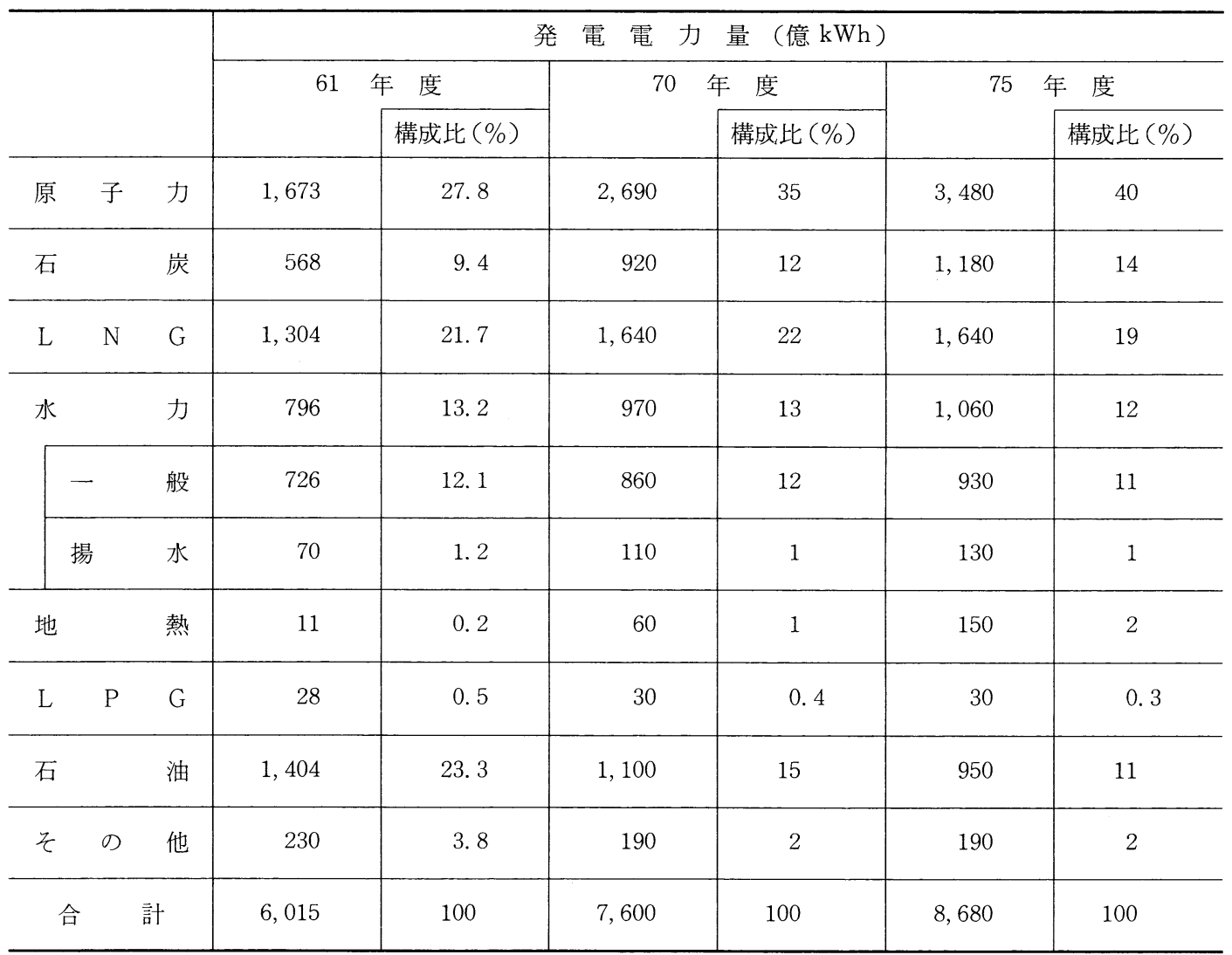

（出所）電気事業審議会 需給部会 中間報告 (62年 10 月)

供給源もASEAN諸国や先進国が大部分を占めるため, 安定供給の面からは評価できよう。しかし, 供給の安 定性は一定量の引き取り義務を伴っているため, 柔軟 性, 弾力性に欠ける面もある。このため, 将来的には, 原子力や石炭を補完する役割を果たしていくところと なろら。

ところで，太陽光発電などの新ェネルギーや，然料 電池などによるコージェネレーション型の新発電方式 については，コストダゥン技術の進歩如何では，ある 程度普及していくところとなろら。しかし，発電の不 安定性, 経済性の点からは, 既存の電力供給システム にとって替わることにはならないものと思われる。

\section{2 供給力の将来イメージ}

2000 年 (昭和75年度) における電源構成は, 表 3 に示 すとおりである。

原子力ならびに石炭火力のウェイト増大に伴ら夏期 補修量の増户, 所内電力分の增大, さらには運用面の 弾力性確保面などを考慮すると, 最大電力に対しては,
1.3 倍程度の電源設備が必要になるものと考光られる。 2000 年時点では, 最大出力 1 億 6,300 万W $\mathrm{kW}$ 対して, 2 億 1,200 万 $\mathrm{kW}$ の設備が必要となる。供給力構成に ついては，先に述べた供給設備の変化の方向性を考虑 すると，以下のと打りである。

まず, ベース供給力としては, 経済性および然料調 達の安定性などに優れている原子力, さらには石炭火 力を用いることが望ましいであろら。ピーク需要ない しは予備力に対するものとしては, 負荷応答性や出力 調整機能に優れる石油火力や揚水，貯水式水力などが ふさわしいと考えられる。ベース需要とピーク需要の 中間的性格を持つミドル需要に対しては，LNGない しは石炭火力が適当であろう。

この結果, 昭和75年度の電源構成に扎いては，原子 力は 5,300 万 $\mathrm{kW}$ となって，全設備の $25 \%$ を占めるよ らになる。またべース供給力として活用されることか ら, 全発電電力量の $40 \%$ まかならものと期待されて いる(表 4 )。一方, 石炭火力は, 徐々にそのウェイト 
を高めていき，75年度には 2,300 万W，全設備の 11 \%を占めるところとなる。これに対して, 石油・LPG 火力は, 61 年度末の 5,694 万W $\mathrm{kW}, 75$ 年度には 4 , 660 万W と, 設備量そのものが減少するものと見込 まれる。したがって, 電源設備に占めるウェイトも, $36 \%$ から $22 \%$ へと著しく低下していき, 脱石油化がは かられるのである。

3.3 供給設備における課題と対応の方向

3.3 .1 原子力の経済性向上と条件整備

原子力を供給力の主軸として位置づけるためには, 安全性, 信頼性の向上とともに, 経済性向上を図るこ とが重要である。このためには, 建設単価の低減や高 燃焼度化による燃料サイクルコストの低減などを, こ れまで以上に積極的に推進する必要がある。

建設費のコストダウンについては，標準化された 大容量ユニットの採用, 大規模開発によるスケールメ リットの追求，リピート効果の活用が不可欠である。 しかしながら，新型炉の一層の大型炉開発を指向する 場合には, 開発効率などを考慮すると, 適正ユニット サイズの選択, 開発ピッチの維持, 計画工程通りの建 設推進が重要となろら。

また，ウラン資源の有効利用や経済性の向上を図る ためには, 高性能炉心などを備えた軽水炉の導入促進 が重要である。これとともに，原子燃料サイクルの自 立化を進めることによって, 混合原子燃料を実用化す ることが必要である。

\section{3 .2 石炭利用拡大八の対応}

今後の石炭火力については, ベース供給力としての 役割と, ミドル供給力としての役割の両者が求められ ることが予想される。このためミドル運用機能を十分 に発揮させるための負荷追従性の向上と, 建設費の低 減が重要であろう。さらには, 燃料費低減の観点から は, 供給ソースの分散化, 多様化などはもちろんのこ と, 石炭市場のフリーマーケット化や開発輸入など弾 力的な調達体制の確保が必要であろら。このほか, 石 炭輸送に伴らュールチェーンの確立, 石炭灰処理の技 術開発などが問題となろら。加えて最近では, 炭酸ガ スの増大に伴ら温室効果問題, 広域的な酸性雨問題な ぞ, 地球規模での環境問題が発生しつつある。こうし た環境問題への取り組みも重要な課題と考えられる。

3.3 .3 計画と運用の弾力性の確保

原子力をはじめとして, 電源設備が運用に供せられ るまでには，長期間を要する。一方，長期的な需要想 定には，常に不確実性を伴うことを避けることができ ない。このため, 電源開発にあたっては, 大規模開発
方式に, LNGコンバインド，石炭ガス化コンバイン ドなど，小回りのきく，モジュール型電源の増強を併 行して進めていくことが, 開発の効率性を高めていく こととなろら。

ところで, 柔軟性の確保は, 電源開発の面ばかりま ではない。電力品質向上へ向けての要請の高まりから, 時々刻々变動する需要に応動して周波数調整を行うこ とのできる, 柔軟な運転能力の確保もまた重要となる。 この点からは, 原子力の負荷即応機能や, 揚水式水力 の揚水時における $\mathrm{AFC}$ 運転機能の保持が課題となろ 5 。

\section{3 .4 広域運営の推進}

従来に増しての安定供給の確保, コストダウンの推 進を目指していく上では，新して時代に即応した広域 運営を進めていくことが求められる。たとえば，海外 エネルギー資源の導入, 技術開発, 原子力燃料サイク ルの確立, 非常災害時の応援など, 全国レベルでの相 互協力を推進する必要があろう。また, 広域開発につ いては，異なる電源種別，異なるユニットサイズなど， 弾力的な開発形態を推進することも忘れてはならない ことである。さらには, 広域融通については, 長期的 な需給構造の差を活用した経済融通の拡大はもとより, スケールメリット追求による設備余力の活用や, 原子 力設備の増加による補修量の増大, 補修時期の変動へ の対応といった面での, 新たな広域運営の拡大策を検 討していくことが重要である。

\section{4. 今後の技術開発}

電気事業が，さきに述べたとおりの社会の变化に的 確に対応していくために, 技術開発の役割は一層重要 になっている。

さらに, 将来の予想しがたい変化に対応していくた めにも，技術ポテンシャルを高めておく必要があろら。

4.1 技術開発の方向性および主要開発課題

4.1 .1 技術開発の方向性

昭和 60 年策定の長期技術開発戦略および電気事業の 21 世紀ビジョンの検討の結果から，電気事業に関連す る技術開発の方向性は, 表 5 のように予測されている。 これは，最近のエネルギー情勢や技術開発の状況と， これらの将来の姿を大胆に予測し，当該技術の実現性 や開発資金見通しなども踏まえ作成されたものである。 電気事業の取り組みとしては，原子力と石炭を中心 としたプロジェクトの重点選別を指向することとし，

従来から進めてきた改良型軽水炉 ( A-BWR， A-PWR) 次世代型軽水炉や高速増殖炉の開発および プルトニウム利用を含む原子燃料サイクル技術 
表 5 電気事業に関連する主要技術開発課題と開発目標

\begin{tabular}{|c|c|c|c|c|}
\hline & \multicolumn{3}{|c|}{ 各 技 術 開 発 } \\
\hline & & \multirow{2}{*}{$\begin{array}{c}2000 \text { 年 以 前 } \\
\text { - 改良型軽水炬 } \\
(\mathrm{A}-\mathrm{PWR}, \mathrm{A}-\mathrm{BWR}) \\
\text { ・原子燃料サイクル }\end{array}$} & $2000 \sim 2030$ 年 & 2030 年 以降 \\
\hline & 原子 力 技 術 & & $\begin{array}{l}\text { - 次世代型軽水炉・高速土 } \\
\text { - 廃 炉 } \\
\text { - 原子力新立地 }\end{array}$ & $\begin{array}{l}\text { ・核融合炉 } \\
\text { ・多目的高温ガス炉 }\end{array}$ \\
\hline エ & 石炭利用技術 & - CWM & $\begin{array}{l}\text { - 石炭ガス化複合発電 } \\
\text { ・石炭液化 } \\
\text { (技術確立時期) }\end{array}$ & \\
\hline $\begin{array}{l}\text { ル } \\
\text { ギ }\end{array}$ & 高効率発電技術 & ・高効率ガスタービン & $\begin{array}{l}\text { ・超々臨界圧火力 } \\
\quad\left(350 \mathrm{~kg} / \mathrm{cm}^{2} 650^{\circ} \mathrm{C}\right) \\
\text { ・超電導回転機 }\end{array}$ & \\
\hline $\begin{array}{l}\text { । } \\
\text { 供 } \\
\text { 給 } \\
\text { 技 }\end{array}$ & 新エネルギー技術 & 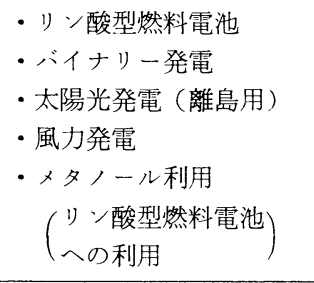 & $\begin{array}{l}\text { - 溶融炭酸塩型燃料電池 } \\
\text { - 高温岩体発電 } \\
\text { • 太陽光発電 (住宅用) } \\
\text { • 波力発電 } \\
\text { - 海洋温度差発電 }\end{array}$ & $\begin{array}{l}\text { ・水 素 } \\
\left(\begin{array}{l}\text { 水からの低コスト } \\
\text { 製造技術 }\end{array}\right)\end{array}$ \\
\hline \multirow[t]{3}{*}{ 術 } & エネルギー貯蔵 & & \multicolumn{2}{|c|}{$\begin{array}{l}\cdot \text { 圧縮空気電力貯蔵 } \\
\cdot \text { ・ライホイール貯蔵 }\end{array}$} \\
\hline & 大 電 力 送 電 & & \multicolumn{2}{|c|}{ • 超電導送電 } \\
\hline & そ の 他 & & & • 宇宙発電 \\
\hline $\begin{array}{l}\text { エ利 } \\
\text { ネ用 } \\
\text { ル } \\
\text { ギ技 }\end{array}$ & 熱 利 用 技 術 & $\begin{array}{l}\text { ・スーパーヒートポソプ } \\
\text { ・電気加熱 } \\
\left(\begin{array}{l}\text { プラズマ加熱レー } \\
\text { ザー加熱等の普及 }\end{array}\right) \\
\end{array}$ & & \\
\hline I術 & 輸送技術 & $\begin{array}{l}\text { ・リニアモーターカー } \\
\text { (都市間交通用) }\end{array}$ & $\begin{array}{l}\text { - 電気自動車 } \\
\text { (本格的普及) }\end{array}$ & $\begin{array}{l}\text { リニアモーターカー } \\
\text { (高速大量輸送用) }\end{array}$ \\
\hline
\end{tabular}

石炭ガス化複合発電など石炭利用技術 の開発に重点を置くこととする。自然エネルギー利用 は, 局地的, 補完的なものとして位置づけ, 将来のコ ストおよび技術開発の進展状況を見守りながら, 必要 な技術開発を進める。

また原子力, 石炭に次ぐものとして, 高効率発電の ための燃料電池, 負荷率向上のための電力貯蔵用新型 電池について効率的に開発を進めることとし, さらに, スーパーヒートポンプや電気自動車, 電気加熱などの 電気利用技術等についても積極的に技術開発を進める。 設備の高度利用を図るための設備診断技術などの開 発, 環境対策技術の高度化等も引き続き推進する。 高度情報化対応技術や人工知能などの次世代技術に も積極的に取り組むとともに，新素材や先端エレクト ロニクス, バイオテクノロジーなどの技術動向にも注
視し，技術シーズの把握に努めて，社会変化や未来に 対する適応性を強化し, 技術ポテンシャルを高める。 とくに電気の供給技術ならびに利用技術に大きなイン パクトを与えると期待される超電導技術開発を積極的 に推進する。

将来的には, 水素エネルギーがそのクリーンさやエ ネルギー密度の高さから, 未来の新エネルギーとして 注目されており，低コストの製造技術が確立されれば， 各種エネルギー源として広く普及していくものと思わ れるので, 発電への利用技術を含め, その技術開発動 向を注視していく。

\section{1 .2 主要開発課題}

(1) エネルギー供給技術

電気事業に対するニーズに応え, 電気事業が社会に 貢献するために技術開発の果たす役割は大きい。 


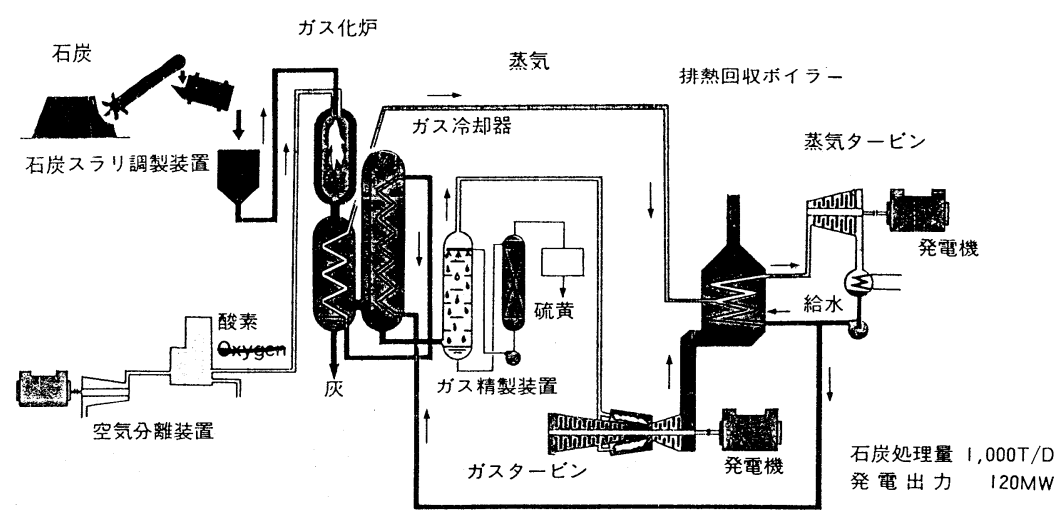

図 1 クールウォータ実証プラント概念図

そこで, 実用化度合, 供給構造, 負荷形態への影響 度合を考慮しつつ21世紀の電力供給構造に影響を及ぽ す可能性のある技術開発項目について整理した。

(a) 原子力利用技術

軽水炉型原子力発電は, 過去 20 年余にわたる技術向 上の努力と経験の蓄積とにより, 技術·経済性の両面 において優れた実績をあげ，その実用性は定着するに 至っており, 今後も長期間にわたり原子力発電の主流 となる炉型である。

したがって, 今後も在来型軽水炉の高度化抢よび改 良型軽水炉の導入, さらに次世代型軽水炉技術を確立 し, 軽水炉技術の高度化を進める。

原子然料サイクルについては, 自主技術を確立し, セキュリティ, 経済性を考虑しつつ国産化·自立化を はかる。

原子力施設の廃止措置については, 作業者の安全性 の一層の向上, 作業の効率化などのための技術の開発 を進める。

高速増殖炉は, 軽水炉の次期炉型として位置付けら れ，その実用化時期は2030年頃と予想される。

そのため, 高速増殖炬が軽水炉と安全性・経済性に おいて競合しらる技術の確立を図る。

(b) 石炭利用技術

石炭ガス化コンバインドは燃料多様化, 環境適合性 に優れた高効率の発電方式であり, 電力供給技術とし て原子力発電に次ぐ主流を占めるものと考えられる。 この技術は21世紀初め頃には実用化し, 電源構成のべ ストミックス確立を目指した石炭火力導入の中心とな ると期待される。

石炭ガス化コンバインド発電は環境適合性において, 石炭生焚きやCWM(Coal Water Mixture) 火力より優
れているが，より一層の精密脱硫による酸性雨防止対 策や，精密脱硝による光化学スモッグ防止対策などの 大気污染防止対策技術に加兄，石炭灰の有効利用技術 についてもさらに力を入れて開発する必要がある。ま た, 化石燃料発電の課題である炭酸ガス増加対策につ いても検討が必要である。

CWMは石炭のハンドリング技術として位置づけら れる。

石炭液化の用途は主に自動車や化学工業用の原料と して利用されると思われる。発電用燃料としては, 産 炭地液化による輸送費負担軽減の可能性も考えられる ので，技術開発動向を注視しておく必要がある。

(c) 高効率発電技術

高効率発電技術としては, 高効率ガスタービン, 超 々臨界圧火力, 超電導発電機などが考えられる。

高効率ガスタービンについては, 今後, 冷却方式, 燃焼器, タービン翼の材質などの技術開発課題が解決 され, 石炭ガス化コンバインド発電用として実用化さ れることが期待される。

タービン入口蒸気を高温高圧にして熱効率の向上を はかる超々臨界圧火力は, ボイラー, タービンの材料 開発が行われ，熱効率44\%台の実現が期待される。

超電導発電機は，重量·容積が在来機の約 $50 \%$ とな り, 機器コスト低減がはかれるとともに, 効率が在来 機の $98.5 \%$ より $0.5 \sim 0.7 \%$ 向上する。さらに，同期リ アクタンスを小さくすることがでさるので，系統安定 度を向上させることも可能である。しかしながら，超 電導線材の開発, 巻線, 支持構造物などの要素の性能 向上および信頼性向上を目的とする製造技術の確立な ぞ課題が多く，今後の技術開発が期待される。

(d) 新エネルギー技術 


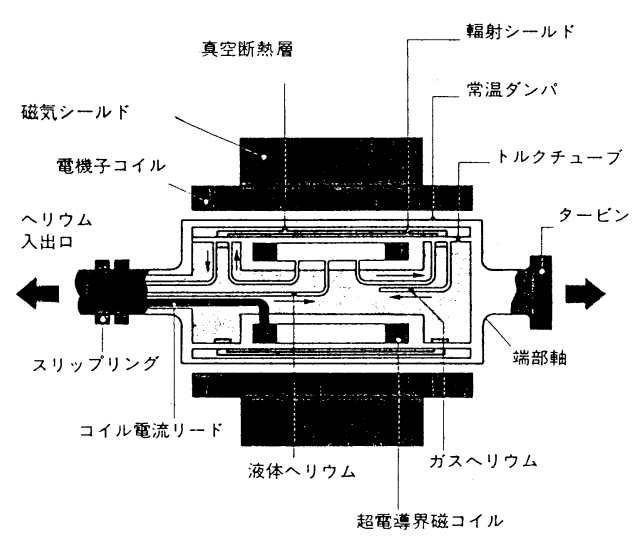

図 2 超電導発電機回転子の構造

然料電池は発電効率が高く, 環境上の問題が少ない ため, 需要地の近くに設置できること, 然料として天 然ガス, 石油, メタノールから石炭まで使用可能であ ることなどの特徵を有しており, 高効率発電方式とし て火力代替用集中型発電から分散型発電, コージェネ など多様な電源形態として利用できる。

リン酸型については2000年頃までに実用化され，電 力用としては熱供給を加味した分散型電源として導入 される可能性がある。

また，コージェネ用ソースとして，ガスタービン， ガスエンジンなどがあるが，大気，騒音等の環境面お よび，得られる電気と熱のエネルギー比率などを考え ると, 燃料電池が主力となっていく可能性が強い。

溶融炭酸塩型は, 現在, 耐熱·耐蝕材料などの要素 技術開発の段階にあり，実用化はリン酸型に比べ遅く 2010年以降となる見通しである。発電効率が 45 ～50\% と高いこと，石炭ガスを利用できるなど然料の多様化 がはかれることなどから，将来，火力発電代替として 導入の可能性がある。

固体電解質型は現在基礎研究段階にある。発電効率 が $50 \%$ 以上, 反応温度が $1,000^{\circ} \mathrm{C}$ と熱利用の点でも優 れていることから将来的には高品位の排熱利用も考え られ, 燃料電池のかなり主要な位置を占めると思われ る。

バイナリーサイクル発電, 高温岩帯発電は2000年頃 実用化し, 有望地点から数万 $\mathrm{kW}$ 規模で部分的に導入 が進さ。

太陽光発電は周辺装置も含めたコストダウンが最大 の課題であるが，主として住宅用等の補完電源として 導入されていく可能性が大さい。また離島用ディーゼ ル発電設備とのハイブリッド方式としても適宜導入さ

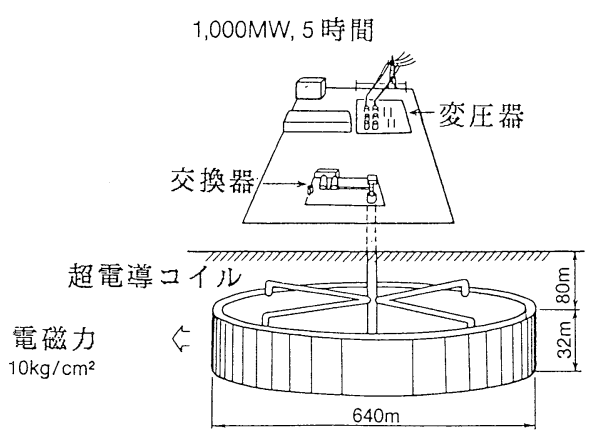

図 3 超電導エネルギー貯蔵システム(SMES)

れていくと思われる。

風力拈よび海洋ェネルギーは自然条件の良い所の局 部導入にとどまる。

メタノールは当面大規模発電用然料としての利用は 考えにくいが, 燃料電池への利用の可能性は考えられ る。

水素は水から低コストで製造する技術が確立すれば， その用途は非常に広いが，21世紀後半以降の技術と推 測される。

(e) エネルギー貯蔵技術

エネルギー貯蔵技術としては, 新型電池, 超電導エ ネルギー貯蔵, 圧縮空気貯蔵, フライホイールなどが ある。冷房需要の増加に伴って, 需要の格差の拡大が 予想される 21 世紀においては, エネルギー貯蔵の必要 性はさらに高まってくると考えられる。

ナトリウムー硫黄電池などの新型電池は, 電力供給 側で揚水代替, 需要側で非常用電源, $\mathrm{CVCF}$ (定電圧 定周波数), 電気自動車, 不安定なエネルギーの平滑化 など広い用途が考えられるが，導入の可能性は経済性， 信頼性の向上如何による。

超電導エネルギー貯蔵は, 揚水代替用のものでは電 磁力を支持するための強固な岩盤の立地問題, 磁界の 影響などの環境問題があり，わが国での大規模な導入 は困難と思われる。系統安定化用, リニアモーター カーの電源用など速応性を利用した小規模なものの導 入の可能性はある。

圧縮空気によるエネルギー貯蔵は，立地点の制約が 多く，わが国では適地が少ない。

フライホイールによるエネルギー眝蔵は, 数時間以 上の貯蔵, 大容量貯蔵は難しく, 特殊な用途に限定さ れる。

(2) エネルギー利用技術

(a) 熱利用技術 
スーパーヒートポンプは1995年頃実用化され，産業 用, 大型ビル空調用などに普及が拡大していくと思わ れる。

蓄熱技術もヒートポンプとの組合せにより地域冷暖 房，ビル空調などに普及が拡大していく。

電気加熱はすでに実用化されているものも多いが, 今後はビーム加熱などに関する技術が確立し, 微細加 工，超高温加工などの先端技術分野においてかなり普 及することが予想される。

また，一般家庭においては，人口の高龄化，女性の 社会進出等を背景としたホームェレクトロニクス, オール電化住宅の進展など電化生活が進み, 電気機器 の大容量化が予想される。これに伴い, 電力の $200 \mathrm{~V}$ 利用も進展するものと思われる。

\section{(b) 輸送技術}

輸送分野へのエネルギー利用技術として，電気自動 車の普及, リニアモーターカーの実用化などが予想さ れる。

現在の鉛電池を搭載した電気自動車は, 1 充電走行 距離で $80 \mathrm{~km}$, 最高速度で70 $80 \mathrm{~km} / \mathrm{h}$, 充電時間 8 時 間程度であり，大規模な普及には至っていない。

ナトリウム一硫黄電池のように鉛電池の $2 \sim 5$ 倍程 度のエネルギー密度を持った新型電池を電気自動車に 搭載できれば, 1 充電走行距離で $200 \mathrm{~km}$ 以上の性能 が実現でき，用途によってはガソリン車と競合し得る 可能性がある。

軽トラックの電力消費率を $3 \mathrm{~km} / \mathrm{kWh}$, 走行距離を $12,000 \mathrm{~km} /$ 年として年間使用電力量を試算すれば， 1 台当たり約 $4,000 \mathrm{kWh}$ 程度となり, 夜間電力を使用し て充電するとすれば，負荷率向上効果は相当大きいも のとなる。

リニアモーターカーは, 東京一成田間のような空港 アクセス用や, 東京一大阪間を 1 時間で結ぶ高速大容 量輸送用として実用化が予想される。

とくに, 高速大容量輸送の場合には, 電力需要の増 大, 電圧変動·高調波などの系統への影響など電力事 業に与える影響はきわめて大きいと思われる。

(3) 先端技術

半導体技術の飛躍的進歩によるエレクトロニクスの 発展はいらに及ばず, メカトロニクス, バイオテク, ロジーあるいは海洋技術, 宇宙技術など新たな技術革 新のシーズが多方面に開花しつつある。

これら先端技術を電力エネルギー分野に適用する事 により, 経営効率の向上をはかり得る可能性は大いに ある。
また先端技術の開発，適用動向によっては，エネル ギー需要構造に変化を生じる可能性もある。このため, これらの動向を充分注視し, 電力供給の総合効率に有 利となる技術シーズの掘り起こしにつとめ, 利用可能 なものについて積極的に取り組んでいく必要がある。

とくに，高温超電導が実現された場合のインパクト は非常に大きいものと考えられ，今後の材料開発に注 視していく。

その他の未来技術として, 宇宙発電と多目的高温が ス炉があげられる。

宇宙発電は太陽発電衛星を宇宙空間に打ち上げ，得 られる太陽ェネルギーを地上に送電するシステムであ るが, 輸送コスト, 電池本体コストおよび受電アンテ ナ規模などの問題があり，実用化は当面無理と思われ る。

多目的高温ガス炉は従来の原子炉より高温 $\left(1,000^{\circ} \mathrm{C}\right.$ 程度)の熱を取り出すことができる原子炉であり，石 炭のガス化·液化や化学工業や鉄鋼業の熱源への利用, さらには, 将来のエネルギ一源として期待される水素 の製造などへの利用が可能であるため, 今後の動向を 見守る必要がある。

5. おわりに

「電気事業の 21 世紀ビジョン」などをもとにして，21 世紀へ向かっての電力需要, 供給力および技術開発動 向について述べてきた。わが国経済社会は，衣食住と いら基礎的な要件を満たしたといわれる。今後，21世 紀に向かっては，ソフト化・サービス化の傾向は, こ れまで以上に強まるところとなり, 産業構造, 経済構 造においても，大きな変化が予想されるところである。 このよらな社会変化の中で, 電気事業にとっての経営 課題は，これまでに述べた需要面での電力品質に対す る要求水準の高度化への対応や, 電力安定供給へ向け ての努力など, 需給面での課題ばかりではない。さら には, 今後の時代を形成するキーワードのひとつとし て，技術革新があげられるが，経営課題が技術開発に 尽きるわけではない。来たるべき時代を担ら電気事業 として，取組むべき課題は山積している。例えば，事 業活動内容が世界の最前列に立ちつつあることから， わが国電気事業にとっての国際的な責務は急増してい き, 電気事業としての, 国際協力が大きなテーマとし て浮かび上がってこよう。また, 電気事業が総合地域 産業として成長していくことも, 課題の一つである。 たとえば，通信事業，熱供給事業などを通じて，電気 事業が地域の総合振興に貢献するなかで, 自らの経営 資源の最大限の活用を目指すといったことも必要であ 
る。地域自らの活性化努力を求められる将来において, 都道府県といら最大の地方行政単位を超えて, かつ地 域社会と密接な関係を持つ, 電気事業にとっては, そ れは社会的責務といった方がふさわしいからである。

規制緩和，国際化といった社会的潮流の中で，電気 事業の活動できる場は広がりつつある。一方, エネル
ギ一間競合のもと, 他のエネルギー源との競争も激し

く，また厳しいものとなっていこう。このような状況 においては, 各電力会社の経営方針およびその結果が, 厳しい目で比較されていくことになるであろら。すな わち, 21世紀の電気事業は文字どおり, 協調と競争と いら状況の中に置かれているに違いないのである。

\title{
Vision of the Japanese Electric Utility Industry for the 21st Century
}

\author{
Masami UEDA*1, Makio FUJIWARA*2 \\ $\left(\begin{array}{c}{ }^{* 1} \text { Engineering Research \& Development Administration } \\ { }^{*} \text { General Planning Department } \\ \text { Tokyo Electric Power Company }\end{array}\right)$
}

SYNOPSIS :- Our economic society seems to have reached a great turning Point. If we focus our attention on the electric utility industry and its surroundings, we find that situation has remarkably changed in recent years. The requests for high-quality electricity supply have been increasing. Customers' needs have been diversifying. Additionally, customers have been inclined to amenities. Consequently, those changes promote the competition among energy sources and the electric utility industries are required to consider its future business activities fundamentally.

In such situation, it is important for the electric utility industry to shift its awareness from supply to sales, and to make broad technological development in the electric power use and its supply. Therefore, the electric utility industry should fully understand the great possibility and necessity of technological development in energy industries and make efforts for developing independent technologies under the long-term R\&D stralegies

In this report, at first, supply-demand outlook for electricity in Japan is discribed, which is based on the interim report (October 1987) of the Electric Utility Industry Council's Supply-Demand Working Group. At last, we explain the important fields of technological development on which the electric utility industry must place more emphasis.

\section{Key Words}

Supply-demand outlook for electricity in Japan, Electricity utilization technologies, Electric power supply technologies. 